\title{
ANALISIS IMBAL HASIL DENGAN AUTOMATIC TRADING DALAM PERSPEKTIF MONEY MANAGEMENT: STUDI EKSPERIMENTAL DENGAN EXPERT ADVISOR PADA PASAR FUTURES
}

\author{
Paulus Candra a \\ *abc Magister Manajemen, Fakultas Ekonomi dan Bisnis, Universitas Tanjungpura, \\ Pontianak \\ *Email : Paulus.candra87@gmail.com \\ (Diterima Desember 2019; Disetujui Mei 2020; Dipublikasikan Oktober 2020)
}

Abstrak

In this study an experimental study was using automatic trading by develop an expert advisors to works with backtesting simulation from January 2010 to December 2019 to research the performance returns of the double moving average cross strategy with 6 pairs from SMA (10.30), SMA $(10.50)$ and SMA $(10,100)$ and EMA $(10,30)$, EMA $(10.50)$, and EMA

$(10,100)$. EMA performance $(10.30)$ that given treated 3 types of money management methods, namely fixed lot, fixed \% lot, and martingale $(1.5 \mathrm{x})$ in the GOLD futures market (XAUUSD) at 1 hour timeframe which will be compared with descriptive analysis.

This study shows that the EMA (10.30) without using money management (fixed lot) method shows the most optimal results with a total return $63.5 \%$ in the futures market which is higher than the passive strategy. The experimental results show that the fixed $\%$ lot method decreases performance with lower returns and increases risk when compared without using money management (fixed lot). While the most optimal money management method is martingale (1.5x) with the achievement of a total return $6,610.56 \%$ and a risk adjusted ratio (RAR) at $5.02 \%$.

Individually, the method that gives the highest yield is shown by EMA (10.30) on the fixed lot method with a total return of $63.5 \%$ and RAR at $2.41 \%$, EMA (10.30) on the fixed sum lot method with a total return of $62.77 \%$ and RAR $1.52 \%$ and EMA (10.100) with a total return $6.610 .56 \%$ and RAR $5.02 \%$ on the martingale method simulated using expert advisors in the futures market.

Keywords: Moving Average, Money Management, Gold, Return, risk adjusted return, Martingale, Fixed Lot, Fixed Ratio, Expert Advisor, Automatic Trading.

\section{LATAR BELAKANG}

Pasar Gold futures menjadi salah satu instrumen alternatif yang digemari oleh para investor dan trader. Emas yang menjadi salah satu instrument safe haven menjadi instrumen investasi yang memberikan pengembalian yang baik. Dalam pasar gold, fluktuasi harga menjadi incaran para spekulan serta kenaikan harga gold secara historical yang menanjak naik menjadi incaran para investor.

Pemilihan double moving average yang tepat bagi para investor perlu dilakukan secara cermat dengan penyesuaian dan analisis yang mendalam. Jika pemilihan pasangan strategi double MA cross dilakukan secara acak tanpa melewati analisis maupun riset bisa mengakibatkan kinerja yang tidak sesuai dengan imbal hasil yang diharapkan. Penelitian double moving average cross yang dilakukan oleh tapa, et al (2016) pada pasar FBMKLCI index, Boonkrong, et al (2017) pasar SET50

*corresponding authors e-mail : Paulus.candra87@gmail.com Online ISSN: 2721-4230 | Print ISSN: 2721-4281 DOI : http://dx.doi.org/10.26418/ejme.v8i4.43637 
index , serta Bahsan (2019) pada pasar foreign exchange EURUSD menunjukkan bahwa pemilihan pasangan double moving average cross yang tepat dapat memberikan performa yang lebih baik dibandingkan dengna strategi pasif.

Money management berperan penting dalam aktivitas trading, seorang yang memiliki strategi baik dan menguntungkan dapat menghasilkan return yang buruk bahkan mengalami kebangkrutan jika menggunakan money management yang buruk. Penentuan money management sangatlah penting dalam mencapai hasil yang optimal bagi para investor maupun trader. Penyesuain money management dengan strategi trading juga diperlukan perhitungan yang cermat, karena money management yang baik dapat merubah hasil sebuah strategi yang baik menjadi buruk, begitu juga sebaliknya.

Kombinasi antara analisa teknikal yang baik dengan implementasi money management yang tepat masih menyisakan ruang untuk pencapaian return yang tidak optimal. Hal ini disebabkan oleh faktor manusia yang melakukan keputusan transaksi tersebut. Trader maupun investor memiliki keterbatasan waktu dalam memantau pergerakan harga sehingga kehilangan beberapa kesempatan dari signal yang diberikan trading rules berdasarkan analisa teknikal yang telah disusun. Selaras dengan kecanggihan teknologi saat ini, behavioural financing dapat diminimalisir dengan menggunakan Expert Advisor di mana pengambilan keputusan dilakukan berdasarkan aturan trading yang telah disusun dengan melakukan aktivitas trading secara otomatis.

\section{KAJIAN LITERATUR}

Praktisi teknikal analis percaya bahwa data harga (price) dan volume masa lalu memberikan informasi penting dan berguna dalam meramalkan pergerakan harga di pasar keuangan di masa mendatang. Taylor dan Allen pada tahun 1992 melakukan survei di daerah London yang menyatakan bahwa sebagian besar trader maupun investor menggunakan analisa teknikal dalam melakukan aktivitas trading, beberapa memadukannya dengan analisis fundamental. Dengan demikian mereka mengemukakan bahwa 90\% dari responden laporan survei dari Taylor dan Allen memakai analisa teknikal untuk melakukan aktivitas trading

Double moving average crossover memang merupakan salah satu analisa teknikal yang mudah digunakan namun diperlukan pemilihan periode yang tepat yang harus disesuaikan dengan karakteristik pasar tertentu. Dalam kajiannya pada pasar Rumania, Anghel (2017) yang menerapkan sistem perdagangan analisis teknis yang didasarkan pada aturan crossover moving average untuk perusahaan yang terdaftar di Bursa Efek Bucharest tidak menghasilkan laba 
yang signifikan, tetapi mengarah pada excess return yang konsisten dan risiko yang lebih rendah dibandingkan strategi buy dan hold untuk investor potensial selama periode $2001-2011$.

Boonkrong,et al (2017) Membandingkan 20 pasang MA cross termasuk Exponential dan Simple Moving average cross dengan Expert Advisor yakni : SMA $(5,10),(5,30),(5,90),(5,200),(10,30),(10,90),(10,200),(30,90),(30,200,(90,200)$. Dan EMA (5,10), (5,30), (5,90), (5,200), (10,30), (10,90),(10,200),(30,90), $(30,200,(90,200)$. Hasil menunjukkan double MA Cross EMA $(10,30)$ memberikan return terbaik sebesar $21.56 \%$ dari rentang waktu 1 januari 2012 hingga 31 desember 2016.

Berdasarkan penelitian Wójtowicz (2016) dengan membandingkan 6 metode money management dalam trading dan investasi. Yakni terdiri dari Metode yang dikenalkan oleh Irene Aldridge, Metode Ralph Vince, Edward Thorp ,Metode Van Tharp ,Metode Ryan Jones (Fixed \% Lot) serta Metode Martingale. Dalam hasil penelitian tersebut, metode money management martingale dan ralph vince memberikan return yang terbaik dengan menggunakan strategi yang sama dibandingkan dengan metode money management yang lain. Masing-masing memberikan return sebesar $1.731 \%$ untuk metode martingale dan $1.453 \%$ untuk metode ralph vince.

Dalam studi penelitian kali ini, penulis akan melakukan perbandingan hasil net return dari 3 pasang strategy double MA cross SMA dan 3 pasang strategi double MA cross EMA dengan dipadukan metode money management dalam matriks berikut :

\section{Matriks Perbandingan Return}

\begin{tabular}{|c|c|c|c|}
\hline Strategi Aktif & Fixed Lot & Fixed $\%$ Lot & Martingale $(1,5)$ \\
\hline SMA $(10,30)$ & Return & Return & Return \\
\hline SMA $(10,50)$ & Return & Return & Return \\
\hline SMA $(10,100)$ & Return & Return & Return \\
\hline EMA $(10,30)$ & Return & Return & Return \\
\hline EMA $(10,50)$ & Return & Return & Return \\
\hline EMA (10,100) & Return & Return & Return \\
\hline Strategi Pasif & Return & & \\
\hline
\end{tabular}


Pada tahap kedua, penulis akan mencari rata-rata dari metode money management yang diteliti dari 6 pasang strategi double MA cross tersebut berdasarkan masing-masing metode money management untuk mendapatkan hasil metode money management yang bekerja paling optimal.

\section{Matriks Perbandingan Rata-rata Return Metode Money Management}

\begin{tabular}{|c|c|c|c|}
\hline Strategi Aktif & Fixed Lot & Fixed $\%$ Lot & $\begin{array}{c}\text { Martingale } \\
(1,5)\end{array}$ \\
\hline SMA $(10,30)$ & \multirow{6}{*}{ Average Return } & \multirow{6}{*}{ Average Return } & \multirow{6}{*}{ Average Return } \\
\hline SMA $(10,50)$ & & & \\
\hline SMA $(10,100)$ & & & \\
\hline EMA $(10,30)$ & & & \\
\hline EMA $(10,50)$ & & & \\
\hline EMA $(10,100)$ & & & \\
\hline
\end{tabular}

Di sisi lain, dari hasil return tersebut, akan dapat disimpulkan bahwa strategi dengan money management mana yang terbaik di antara 6 pasang strategi double MA cross tersebut, yang diimplementasikan metode money management. Dari hasil eksperimen yang dilakukan, pada tahap akhir adalah membandingkan hasil return dari gabungan strategi double MA cross dengan metode money management yang paling optimal dalam penelitian ini dengan kinerja strategi buy and hold.

\section{HIPOTESIS}

H1 : Double MA Cross memberikan return yang lebih optimal dibandingkan dengan return strategy Buy and Hold.

H2 : Strategy Money management Fixed \% Lot memberikan return yang lebih baik dibandingkan Fixed Lot (tanpa money management) dengan strategy double MA cross.

H3 : Strategy Money management Martingale memberikan return yang lebih baik dibandingkan Fixed Lot (tanpa money management) dengan strategy MA cross.

H4 : Strategy Money management paling optimal memberikan return yang lebih baik dibandingkan return aktual pasar (buy and hold).

\section{METODE PENELITIAN}

Jenis dan Sumber Data 
Jenis data yang dikumpulkan adalah berupa data sekunder yang diperoleh dari software Metatrader 4 yang menampilkan pergerakan harga emas (XAUUSD) periode Januari 2010 - Desember 2019.

\section{Strategi Perdagangan (Trading Rules)}

Penyusunan Strategi Perdagangan (Trading Rules) dibagi menjadi dua posisi yang sangat menentukan, yaitu:

Open Posisi dalam perdagangan

Transaksi buy akan dilakukan jika SMA periode pendek memotong (memotong) SMA untuk periode yang lebih lama. Bentuk pembelian ini sering disebut sebagai golden cross yang menunjukkan bahwa pasar bullish .Transaksi Sell akan dilakukan jika SMA periode yang lebih pendek memotong SMA untuk periode yang lebih lama. Eksekusi selalu dilakukan pada Open Price candlestick timeframe H1.

Close Posisi atau Keluar dalam perdagangan

Jika transaksi masih terbuka Buy, maka penutupan order akan dilakukan jika SMA periode pendek memotong ke bawah SMA periode panjang. Perlakukan sebaliknya dilakukan jika transaksi masih open sell, maka penutupan order akan dilakukan jika periode pendek SMA memotong (ke atas) ke periode SMA yang lebih panjang. Eksekusi selalu dilakukan pada Open Price candlestick timeframe H1.

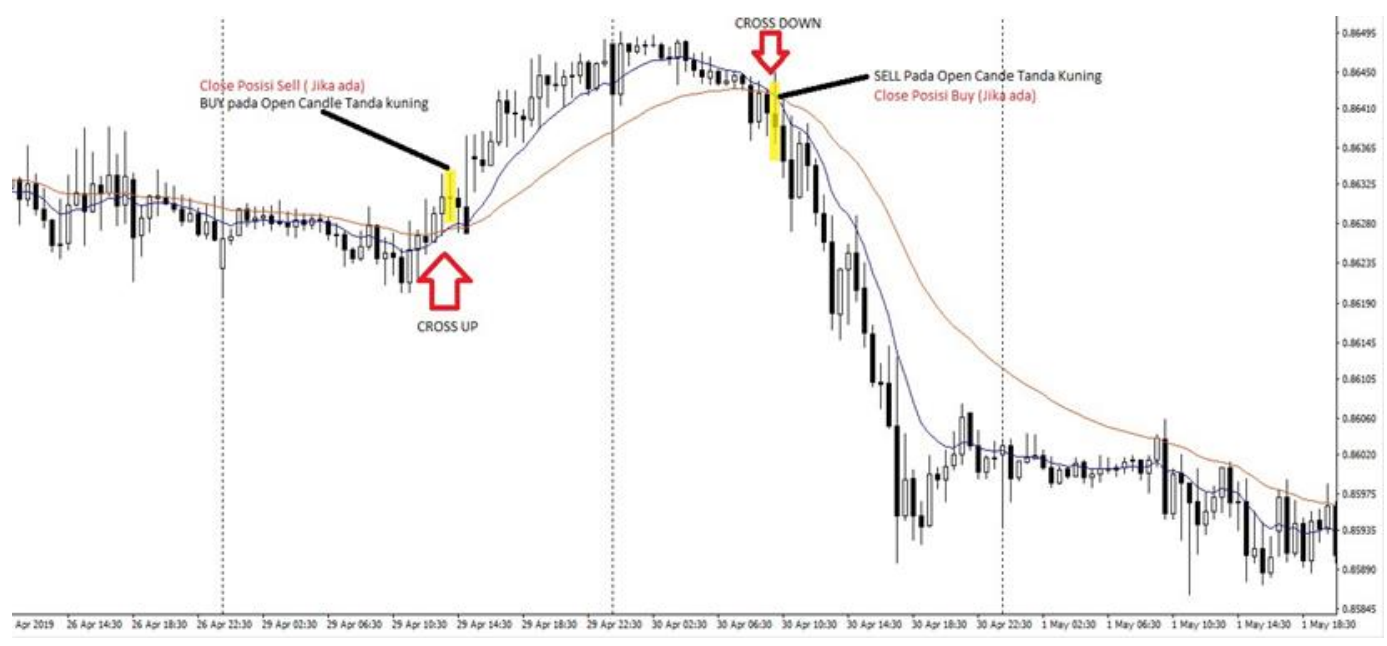

Gambar Trading Rules Strategi double MA Cross SMA 10 dan 30

\section{Money Management}

Pada umumnya money management yang sering digunakan oleh para pendatang baru adalah fixed lot dimana para investor maupun trader menggunakan position sizing yang sama terus menerus dalam melakukan transaksi. misalnya adalah 
pembelian 0,1 lot pada setiap transaksi selama investor tersebut tersebut melakukan transaksi.

Van Tharp membahas lima metode dasar money management (Tharp 2008):

1. Membeli satu kontrak dengan ukuran tertentu dari kekayaan investor.

2. Pembagian porsi kekayaan yang sama di antara semua instrument.

3. Menentukan persentase kekayaan yang terlibat dalam setiap transaksi.

4. Membeli sejumlah kontrak pada pasar tertentu, yang disesuaikan volatilitas pasar selama periode waktu tertentu (mis., Lima hari) dan harus lebih rendah daripada persentase kekayaan yang ditentukan.

5. Membeli sejumlah kontrak dengan pembagian kekayaan yang dibutuhkan untuk mengamankan transaksi menjadi kurang dari nilai persentase kekayaan yang diberikan.

Metode money management Rayan Jones [Tharp 2008, p.161-196] biasanya dikenal sebagai fixed \% lot adalah pengembangan metode pembelian satu kontrak untuk ukuran tertentu dari kekayaan investor. Misalnya, anggaplah investor membeli satu kontrak untuk setiap 10 ribu dolar kekayaan mereka dan mereka mulai dengan 10 ribu dolar; karenanya mereka akan membeli kontrak lain tetapi hanya ketika kekayaan mereka meningkat 100\%. Jika investor memiliki 100 ribu dolar, mereka akan membeli kontrak lain setelah kekayaan mereka meningkat $10 \%$. Ini berarti bahwa investor dengan uang lebih sedikit untuk memulai memiliki peluang lebih kecil untuk melipatgandakan modal mereka. Karena batas ini, Jones telah mengusulkan cara baru untuk mendefinisikan tingkat modal, yang memungkinkan investor yang lebih kecil untuk membeli kontrak baru:

\section{Lot Size $=$ Jumlah Lot saat ini $x$ Delta.}

Di sini Delta menunjukkan nilai moneter yang ditentukan oleh investor yang menggambarkan toleransi risiko (semakin kecil Delta, semakin besar risikonya).

Misalnya, anggap investor memiliki 25.000 dolar. Mereka berinvestasi dalam satu kontrak dan Delta mereka sama dengan 2.500 dolar. Oleh karena itu, mereka akan membeli kontrak lain ketika kekayaan mereka meningkat menjadi $1 \cdot 2.500+$ $25.000=\$ 27.500$. Untuk kekayaan seperti itu mereka harus memiliki 2 kontrak. Ketika kekayaan mereka meningkat menjadi $2 \cdot 2.500+27500=\$ 32.500$, mereka akan membeli kontrak berikutnya, dan seterusnya. Namun, jika mereka kekayaan turun di bawah

27.500 dolar pada titik sebelumnya, mereka harus menjual kontrak yang dibeli sebelumnya (dan tetap dengan satu kontrak).

Money management martingale didefinisikan oleh Larry Williams [Tharp 2008, hlm. 205-207]. Metode ini juga didasarkan pada asumsi bahwa investor menyadari distribusi keuntungan untuk strategi. Selain itu, dalam satu transaksi tunggal, investor berisiko sejumlah nominal atau persentase tetap dari aset mereka. 


\section{Lot Size $=$ Last Lot $($ loss $) *$ Multiplier Factor}

Jenis metode penelitian yang dipilih adalah deskriptif analisis, adapun pengertian dari metode deskriptif analitis menurut (Sugiono: 2009; 29) adalah suatu metode yang berfungsi untuk mendeskripsikan atau memberi gambaran terhadap objek yang diteliti melalui data atau sampel yang telah terkumpul sebagaimana adanya tanpa melakukan analisis dan membuat kesimpulan yang berlaku untuk umum.

Dengan kata lain penelitian deskriptif analisis mengambil masalah atau memusatkan perhatian kepada masalah-masalah sebagaimana adanya saat penelitian dilaksanakan, hasil penelitian yang kemudian diolah dan dianalisis untuk diambil kesimpulannya.

Dalam melakukan penelitian ini, beberapa langkah-langkah yang dilakukan, sebagai berikut :

1. Merancang Expert Advisor dengan 6 pasang strategy moving average cross dengan periode waktu SMA $(10,30)$, SMA $(10,50)$, SMA $(10,100)$, EMA $(10,30)$ EMA $(10,50)$, dan EMA $(10,100)$ dengan 3 tipe Money management yakni Fixed lot, Fixed \% Lot, dan Martingale. Dan Expert Advisor dengan strategy Buy and Hold.

2. Melakukan pengujian backtesting masing-masing strategy MA cross 6 kali ( 6 periode waktu berbeda) dan strategy buy and hold. Menggunakan metode money management fixed Lot.

3. Menghitung return masing-masing dari 6 strategy moving average dan menentukan strategy moving average cross mana yang43paling optimal dengan return tertinggi.

4. Melakukan pengujian backtesting metode money management Fixed \% Lot dan Martingale dengan strategy MA cross yang paling optimal.

5. Menghitung return masing-masing metode money management dengan strategi yang sama pada periode yang sama .

6. membuat perbandingan hasil dari metode fixed \% lot dan martingale dengan metode money management fixed lot.

7. Menghitung return strategy buy and hold.

8. Membandingkan hasil metode money management paling optimal dengan strategi pasif (buy and hold).

\section{HASIL PENELITIAN DAN PEMBAHASAN}

\section{Eksperimen Pertama Double MA CROSS}

Hasil simulasi pada eksperimen pertama menunjukkan bahwa hasil net return tertinggi diraih oleh strategi pasang EMA $(10,30)$ dengan nilai sebesar 69,35\% dari 1920 transaksi dengan rata-rata return sebesar 0,0361\%, diikuti oleh SMA $(10,30)$ dengan imbal hasil akhir yang ditorehkan sebesar 42,30\% dari 2202 transaksi dengan rata-rata return sebesar 0,0192\%,EMA $(10,50)$ dengan net profit sebesar 19,13\% dari 1508 transaksi dengan rata-rata return sebesar 0,0127\% dan yang terakhir adalah EMA (10,50) dengan imbal hasil akhir sebesar 16,34\% dari 1518 
transaksi dengan tingkat return rata-rata sebesar 0,0108\%. Sedangkan pasangan double MA cross yang memberikan imbal hasil negatif terbesar dibukukan oleh strategi EMA $(10,100)$ dengan imbal hasil $(42,21 \%)$ dari 1047 transkasi dengan rata-rata return sebesar $(0,0403 \%)$, diikuti strategi SMA $(10,100)$ yang meraih hasil negatif yakni $(33,61 \%)$ dari 970 transaksi dengan rata-rata return sebesar $(0,0347 \%)$.

Dalam hasil eksperimen pertama ini, pasangan MA cross paling optimal dengan kondisi size lot yang sama (tanpa money management) untuk masing-masing strategi double MA cross adalah EMA $(10,30)$. Dimana return yang dibukukan selama periode Januari 2010 hingga Desember 2019 adalah 69,35\% pada pasar futures emas.

\section{Hasil Simulasi Enam Pasang Strategi Double MA Cross (Fixed Lot) Periode Januari 2010-Desember 2019}

\begin{tabular}{|c|c|c|c|c|c|c|}
\hline \multirow{2}{*}{ Strategy Type } & SMA & \multirow{2}{*}{$\begin{array}{l}\text { SMA } \\
10,50\end{array}$} & \multirow{2}{*}{$\begin{array}{c}\text { SMA } \\
10,100\end{array}$} & \multirow{2}{*}{$\begin{array}{l}\text { EMA } \\
10,30 \\
\end{array}$} & \multirow{2}{*}{$\begin{array}{l}\text { EMA } \\
10,50\end{array}$} & EMA \\
\hline & 10,30 & & & & & 10,100 \\
\hline Total number of trades & 2202 & 1518 & 970 & 1920 & 1508 & 1047 \\
\hline Number of winning trades & 754 & 475 & 284 & 554 & 423 & 261 \\
\hline number of losing trades & 1448 & 954 & 686 & 1366 & 1085 & 786 \\
\hline$\%$ of winning trades & $34,24 \%$ & $31,29 \%$ & $29,28 \%$ & $28,85 \%$ & $28,05 \%$ & $24,93 \%$ \\
\hline$\%$ of losing trades & $65,76 \%$ & $62,85 \%$ & $70,72 \%$ & $71,15 \%$ & $71,95 \%$ & $75,07 \%$ \\
\hline Average profit per trade & $\$ \quad 131,81$ & $\$ \quad 157,88$ & $\$ \quad 213,42$ & $\$ \quad 160,90$ & $\$ \quad 179,14$ & 217,73 \\
\hline Average of loss per trade & $(65,72)$ & $\$ \quad(77,06)$ & $\$ \quad(93,25)$ & $\$ \quad(60,18)$ & $(68,08)$ & $(77,67)$ \\
\hline Minimum Loss & $\$ \quad(0,10)$ & $\$ \quad(0,53)$ & $(0,95)$ & $(0,18)$ & $(0,29)$ & $(0,85)$ \\
\hline Maximum Loss & $\$(814,76)$ & $\$(885,66)$ & $\$(861,27)$ & $\$(762,26)$ & $\$(830,26)$ & $\$(769,36)$ \\
\hline Minimum profit & $\$ \quad 0,01$ & $\$ \quad 0,01$ & $\$ \quad 0,25$ & $\$ \quad 0,13$ & 0,02 & $\$ \quad 0,05$ \\
\hline Maximum Profit & $\$ 1.716,02$ & $\$ 1.730,87$ & $\$ 1.633,81$ & $\$ 1.886,57$ & $\$ 1.736,00$ & $\$ 1.479,31$ \\
\hline Reward to risk ratio & 2,01 & 2,05 & 2,29 & 2,67 & 2,63 & 2,80 \\
\hline Total strategy return & $\$ 4.230,35$ & $\$ 1.634,32$ & $\$(3.361,21)$ & $\$ 6.935,31$ & $\$ 1.913,01$ & $\$(4.221,17)$ \\
\hline Total Return in \% & $42,30 \%$ & $16,34 \%$ & $-33,61 \%$ & $69,35 \%$ & $19,13 \%$ & $-42,21 \%$ \\
\hline Average profit/loss per trade $\%$ & $0,0192 \%$ & $0,0108 \%$ & $-0,0347 \%$ & $0,0361 \%$ & $0,0127 \%$ & $-0,0403 \%$ \\
\hline Lowest balance & $\$ 8.917,86$ & $\$ 7.103,20$ & $\$ 6.190,11$ & $\$ 8.772,60$ & $\$ 8.623,72$ & $\$ 5.367,88$ \\
\hline Highest balance & $\$ 20.657,51$ & $\$ 13.105,12$ & $\$ 12.650,76$ & $\$ 19.532,91$ & $\$ 17.087,59$ & $\$ 11.024,56$ \\
\hline Standard deviation & 142,30 & 165,00 & 201,90 & 150,46 & 166,11 & 191,08 \\
\hline Skewness & 2,90 & 2,33 & 2,49 & 3,43 & 3,23 & 3,10 \\
\hline Kurtosis & 24,69 & 15,98 & 12,64 & 25,21 & 19,97 & 16,24 \\
\hline Risk Adjusted Ratio (RAR) & $1,350 \%$ & $0,652 \%$ & $-1,716 \%$ & $2,401 \%$ & $0,764 \%$ & $-2,110 \%$ \\
\hline
\end{tabular}

Sumber: Data olahan

Dari data diatas, dapat dilihat bahwa dengan strategi paling optimal sekalipun, ekuitas investor/trader tetap pernah mengalami penurunan ekuitas dibawah modal awal sang trader tersebut. Dana ekuitas investor pernah turun hingga ke level \$8.772,60 dari modal awal sebesar \$10.000. namun ekuitas investor pernah menyentuh angka tertinggi di kisaran $\$ 19.532,91$ sebelum akhirnya ditutup pada angka \$16.935.31 pada akhir desember 2019 dengan menggunakan strategi double MA Cross EMA $(10,30)$. Dan untuk mengukur resiko yang terjadi dalam mencapai return, risk adjusted ratio (RAR) digunakan sebagai pembanding untuk menganalisis strategi paling optimal dari keenam pasangan MA tersebut 


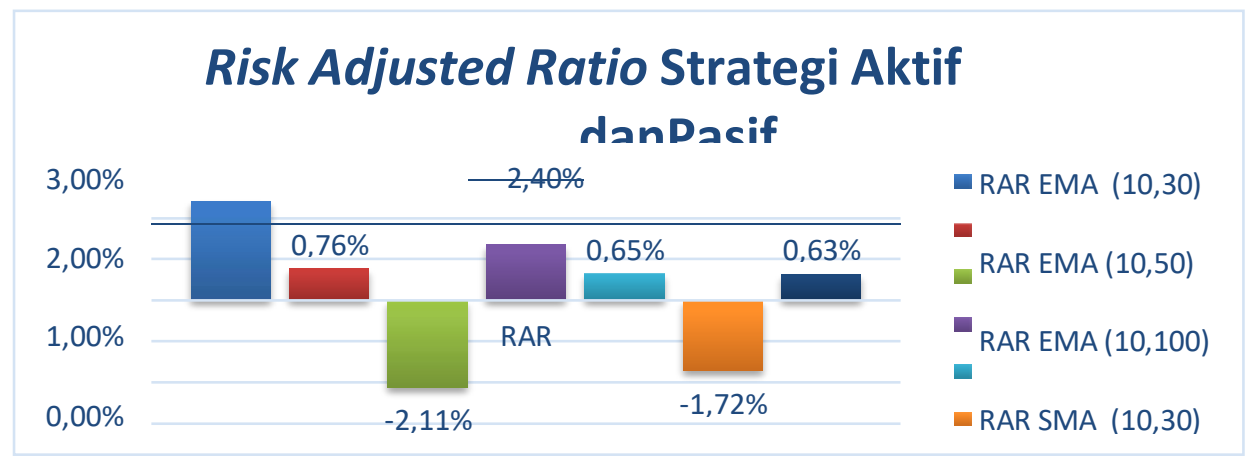

Gambar Grafik RAR Strategi Aktif dan Pasif Tahun 2010-2019

Risk adjusted Ratio (RAR) paling tinggi ditunjukkan oleh EMA $(10,30)$ dengan nilai sebesar 2,401\%. Dan yang kedua tertinggi adalah pasangan SMA $(10,30)$ dengan RAR sebesar 1,350\%. RAR posistif juga dibukukan oleh EMA $(10,50)$ dengan nilai $0,764 \%$, dan SMA $(10,50)$ dengan nilai $0,652 \%$ sedangkan RAR dengan nilai negatif dibukukan oleh SMA(10,100) dan EMA $(10,100)$ dengan nilai masing-masing sebesar $(1,716) \%$ dan $(2,110) \%$.

Maka dari itu, dari segi return berbanding resiko strategi paling optimal dalam simulasi backtesting menggunakan expert advisor pada tahap pertama ini adalah strategi double MA cross pasangan EMA 10 dan 30 yang memberikan risk reward yang lebih baik ketimbang strategi pasif (buy and hold) yang dimana hanya memberikan imbal hasil kepada para investor/maupun trader dengan return sebesar 22,20\% dan RAR sebesar 0,632\%. Ini mendukung hipotesis pertama dimana strategi double MA cross memberikan imbal hasil yang lebih optimal dibandingkan strategi buy and hold, maka (H1) diterima.

Hasil simulasi ini sejalan dengan hasil penelitian yang dilakukan tapa, et al (2018) bahwa strategi aktif khususnya double MA cross memberikan performa yang lebih baik daripada strategi pasif. Dan hal ini juga selaras dengan penelitian Cheung, et al. (2004) dimana dalam penelitiannya, double MA cross pasangan EMA $(10,30)$ membukukan imbal hasil akhir tertinggi dibandingkan dengan pasangan double MA cross lainnya.

Implementasi Metode Money Management Metode Fixed \% Lot dalam Strategi Double MA Cross

Perbandingan Hasil Strategi Aktif dan Pasif dalam Money Management Periode Januari 2010-Desember 2019

\begin{tabular}{|c|c|c|c|c|c|c|c|c|c|c|c|c|c|c|c|}
\hline \multirow[b]{2}{*}{$\begin{array}{c}\text { Strategi } \\
\text { Aktif }\end{array}$} & \multicolumn{5}{|c|}{ Fixed Lot } & \multicolumn{6}{|c|}{ Fixed \% Lot } & \multicolumn{4}{|c|}{ Martingale } \\
\hline & $\begin{array}{c}\text { Jumlah } \\
\text { Transa } \\
\text { ksi }\end{array}$ & $\begin{array}{c}\text { Averag } \\
e \\
\text { Return } \\
\%\end{array}$ & $\begin{array}{c}\text { Total } \\
\text { Return } \\
\%\end{array}$ & $\begin{array}{c}\text { Standard } \\
\text { Deviation } \\
\%\end{array}$ & $\begin{array}{c}\text { Risk } \\
\text { Adjust } \\
\text { ed } \\
\text { Ratio } \\
(\text { RAR })\end{array}$ & $\begin{array}{c}\text { Jumlah } \\
\text { Transa } \\
\text { ksi }\end{array}$ & $\begin{array}{c}\text { Averag } \\
e \\
\text { Return } \\
\%\end{array}$ & $\begin{array}{c}\text { Total } \\
\text { Return } \\
\%\end{array}$ & $\begin{array}{c}\text { Standard } \\
\text { Deviation } \\
\%\end{array}$ & $\begin{array}{c}\text { Risk } \\
\text { Adjust } \\
\text { ed } \\
\text { Ratio } \\
(\text { RAR })\end{array}$ & $\begin{array}{c}\text { Jumlah } \\
\text { Transa } \\
\text { ksi }\end{array}$ & $\begin{array}{c}\text { Averag } \\
e \\
\text { Return } \\
\%\end{array}$ & $\begin{array}{c}\text { Total } \\
\text { Return \% }\end{array}$ & $\begin{array}{c}\text { Standar } \\
d \\
\text { Deviatio } \\
n \%\end{array}$ & $\begin{array}{c}\text { Risk } \\
\text { Adjuste } \\
\text { d Ratio } \\
\text { (RAR) }\end{array}$ \\
\hline
\end{tabular}




\begin{tabular}{|c|c|c|c|c|c|c|c|c|c|c|c|c|c|c|c|}
\hline $\begin{array}{c}\text { SMA } \\
(10,30)\end{array}$ & 2202 & $\begin{array}{c}0,019 \\
\%\end{array}$ & $\begin{array}{c}42,304 \\
\%\end{array}$ & $1,423 \%$ & $\begin{array}{c}1,350 \\
\%\end{array}$ & 2202 & $\begin{array}{c}0,010 \\
\%\end{array}$ & $\begin{array}{c}22,998 \\
\%\end{array}$ & $2,418 \%$ & $\begin{array}{c}0,432 \\
\%\end{array}$ & 152 & $\begin{array}{c}0,379 \\
\%\end{array}$ & $-57,552 \%$ & $6,990 \%$ & $\underset{\%, \bar{c}}{-}$ \\
\hline $\begin{array}{c}\text { SMA } \\
(10,50)\end{array}$ & 1518 & $\begin{array}{c}0,011 \\
\%\end{array}$ & $\begin{array}{c}16,343 \\
\%\end{array}$ & $1,650 \%$ & $\begin{array}{c}0,653 \\
\%\end{array}$ & 1518 & $\begin{array}{c}0,004 \\
\%\end{array}$ & $\begin{array}{c}6,100 \\
\%\end{array}$ & $1,648 \%$ & $\begin{array}{c}0, \overline{244} \\
\%\end{array}$ & 86 & $\begin{array}{c}0,768 \\
\%\end{array}$ & $-66,082 \%$ & $7,078 \%$ & $\begin{array}{c}10,856 \\
\%\end{array}$ \\
\hline $\begin{array}{c}\text { SMA } \\
(10,100)\end{array}$ & 970 & $\begin{array}{c}0,035 \\
\%\end{array}$ & $\begin{array}{c}33,612 \\
\%\end{array}$ & $2,019 \%$ & $\begin{array}{c}1,716 \\
\%\end{array}$ & 970 & $\begin{array}{c}0,039 \\
\%\end{array}$ & $\begin{array}{c}38,221 \\
\%\end{array}$ & $1,791 \%$ & $\begin{array}{c}2,201 \\
\%\end{array}$ & 388 & $\begin{array}{c}0,163 \\
\%\end{array}$ & $-63,344 \%$ & $\begin{array}{c}39,092 \\
\%\end{array}$ & $\begin{array}{c}0,418 \\
\%\end{array}$ \\
\hline $\begin{array}{c}\text { EMA } \\
(10,30)\end{array}$ & 1920 & $\begin{array}{c}0,036 \\
\%\end{array}$ & $\begin{array}{c}69,353 \\
\%\end{array}$ & $1,505 \%$ & $\begin{array}{c}2,401 \\
\%\end{array}$ & 1920 & $\begin{array}{c}0,033 \\
\%\end{array}$ & $\begin{array}{c}62,770 \\
\%\end{array}$ & $2,152 \%$ & $\begin{array}{c}1,519 \\
\%\end{array}$ & 1920 & $\begin{array}{c}1,784 \\
\%\end{array}$ & $\begin{array}{c}3425,079 \\
\%\end{array}$ & $\begin{array}{c}42,463 \\
\%\end{array}$ & $\begin{array}{c}4,201 \\
\%\end{array}$ \\
\hline $\begin{array}{c}\text { EMA } \\
(10,50)\end{array}$ & 1508 & $\begin{array}{c}0,013 \\
\%\end{array}$ & $\begin{array}{c}19,130 \\
\%\end{array}$ & $1,661 \%$ & $\begin{array}{c}0,764 \\
\%\end{array}$ & 1508 & $\begin{array}{c}0,003 \\
\%\end{array}$ & $\begin{array}{c}3,933 \\
\%\end{array}$ & $2,063 \%$ & $\begin{array}{c}0,126 \\
\%\end{array}$ & 12 & $\begin{array}{c}8,006 \\
\%\end{array}$ & $-96,067 \%$ & $9,951 \%$ & $\begin{array}{c}80,451 \\
\%\end{array}$ \\
\hline $\begin{array}{c}\text { EMA } \\
(10,100)\end{array}$ & 1047 & $\begin{array}{c}- \\
0,040 \\
\%\end{array}$ & $\underset{\%}{42,212}$ & $1,911 \%$ & $\underset{\%}{2,110}$ & 1047 & $\begin{array}{c}0,045 \\
\%\end{array}$ & $\begin{array}{c}-\bar{x}, 951 \\
\%\end{array}$ & $1,515 \%$ & $\begin{array}{c}- \\
2,959 \\
\%\end{array}$ & 1047 & $\begin{array}{c}6,314 \\
\%\end{array}$ & $\begin{array}{c}6610,558 \\
\%\end{array}$ & $\begin{array}{c}125,769 \\
\%\end{array}$ & $\begin{array}{c}5,020 \\
\%\end{array}$ \\
\hline $\begin{array}{c}\text { Strategi } \\
\text { Pasif }\end{array}$ & 2609 & $\begin{array}{c}0,009 \\
\%\end{array}$ & $\begin{array}{c}22,199 \\
\%\end{array}$ & $1,347 \%$ & $\begin{array}{c}0,632 \\
\%\end{array}$ & & & & & & & & & & \\
\hline
\end{tabular}

Data diatas menunjukkan performa yang menurun setelah diimplementasikan metode money management fixed lot pada keenam strategi double MA cross. Dalam penggunaan metode money management Fixed \% Lot, penurunan return terjadi pada semua pasangan MA yang diujicoba, serta meningkatkan resiko pada semua strategi yang disimulasikan dalam penelitian ini. Average return SMA $(10,30)$ menurun tipis dari $0,011 \%$ menjadi $0,010 \%$, standar deviasi meningkat dari 1,423\% menjadi 2,418\% dan RAR menurun menjadi 0,432\% dari 1,350\%, dan total return selama Januari 2010 hingga Desember 2019 menurun jika dibandingkan tanpa menggunakan metode money management (fixed lot) yakni menjadi $22,998 \%$ dari $42,304 \%$.

Penurunan average return yang signfikan terjadi pada SMA $(10,50)$ dan EMA $(10,50)$ yakni dari hasil yang positif pada ekperimen pertama menjadi negatif setelah diberlakukan metode money management Fixed \% Lot yakni masingmasing sebesar $(0,004 \%)$ dan $(0,003 \%)$. Penurunan average return juga terjadi pada pasangan lainnya, yakni SMA $(10,100)$ sebesar $(0,039 \%)$, EMA $(10,30)$ sebesar $(0,033 \%)$, EMA $(10,100)$ sebesar $(0,045 \%)$. Resiko yang menanjak paling tajam terjadi pada SMA $(10,30)$ dengan standar deviasi sebesar $2,418 \%$ yang dimana sebelumnya membukukan nilai $1,423 \%$. Standar deviasi SMA $(10,100)$ justru mengecil dari 2,019\% menjadi 1,791\% namun penurunan juga terjadi pada average return dari $(0,035 \%)$ menjadi $(0,039 \%)$.

Seperti yang ditunjukkan dalam table 4.2, pada kolom metode fixed lot (tanpa money management) strategi EMA $(10,30)$ memberikan imbal hasil paling optimal dengan nilai rata-rata return sebesar $0,036 \%$ dengan imbal hasil akhir pada desember 2019 sebesar 69,35\%, standar deviasi yang dibukukan adalah sebesar 1,505\% dan risk adjusted ratio (RAR) sebesar 2,401\% . Imbal hasil paling optimal tetap tidak berubah setelah menggunakan metode money management Fixed \% Lot meskipun memberikan hasil yang lebih rendah yakni tingkat rata-rata return sebesar 0,33\% dengan imbal hasil akhir sebesar 62,77\%, standar deviasi yang lebih tinggi sebesar $2,152 \%$ dan RAR menurun menjadi 1,519\%.

*corresponding authors e-mail : Paulus.candra87@gmail.com Online ISSN: 2721-4230 | Print ISSN: 2721-4281 DOI : http://dx.doi.org/10.26418/ejme.v8i4.43637 


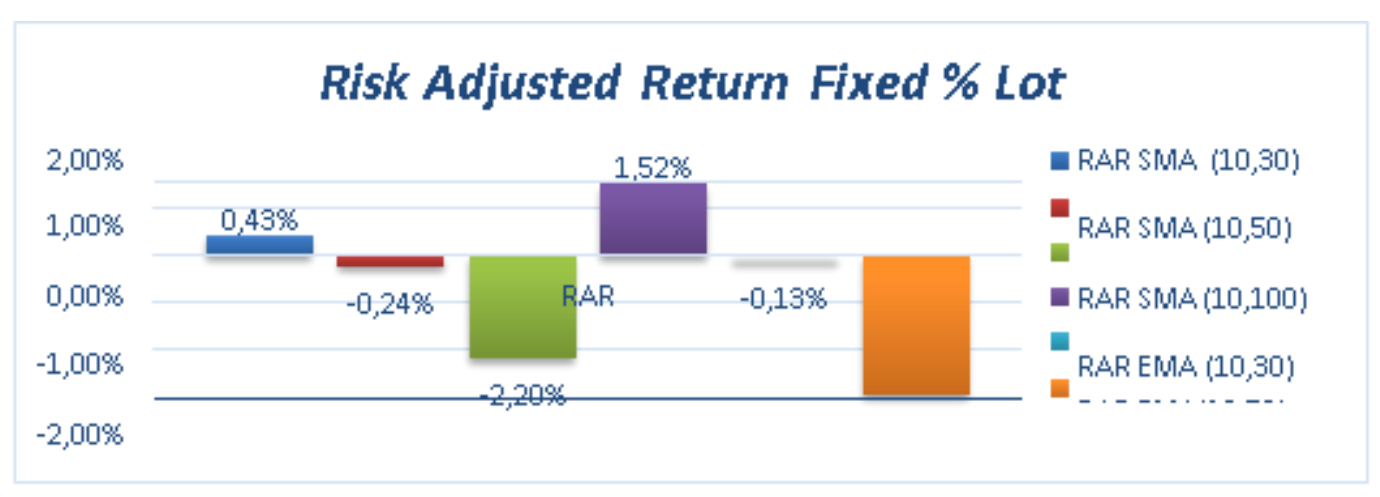

Gambar Grafik RAR Fixed \% Lot Tahun 2010-2019

Hasil ini juga terjadi pada keenam strategi aktif yang diujicoba dalam penelitian kali ini yakni penurunan performa dan peningkatan resiko setelah penggunaan metode money management Fixed \% Lot, ini membuat hipotesis kedua yakni strategi money management Fixed \% Lot memberikan return yang lebih optimal dibandingkan tanpa menggunakan metode money management (fixed lot) ditolak. Maka dalam hasil simulasi ini hipotesis $\mathrm{H} 2$ ditolak dan $\mathrm{H} 0$ diterima, ini berbeda dengan penelitian Wojtowicz (2016) yang menunjukkan return Fixed \% Lot memberikan return yang lebih baik dibandingkan tanpa menggunakan money management. Penurunan performa ini ditunjukkan dikarenakan recovering yang lebih sulit dibandingkan dengan tanpa menggunakan money management. Saat terjadi loss yang beruntun dan ekuitas menurun serta penurunan lot yang terjadi membuat probabilitas menang dari strategi trading sendiri harus lebih tinggi dibandingkan probabilitas loss.

\section{Implementasi Metode Money Management Metode Martingale dalam Strategi Double MA Cross}

Pada implementasi metode money management martingale terjadi variasi performa yang beragam. Terdapat 2 sisi variasi performa yang terjadi saat metode money management ini digunakan. Variasi ini terdiri dari performa yang menurun dan performa yang meningkat seperti yang dapat dilihat pada Tabel 4.2. Untuk performa yang meningkat, ini ditunjukkan saat penggunaan strategi double MA cross pasangan EMA $(10,30)$ dengan perubahan nilai average return yang signifikan dari $0,036 \%$ menjadi 1,784\%. Peningkatan ekstrem ini juga terjadi pada pasangan EMA $(10,100)$ yang justru berubah dari nilai negatif $(0,04)$ menjadi positif $6,314 \%$ dan menjadikan EMA $(10,100)$ menjadi strategi paling optimal dari di pasar futures dari semua strategi yang diteliti.

Disisi lain, metode money management martingale merubah performa strategi lainnya menjadi negatif. Ini dapat dilihat pada pasangan SMA $(10,30)$ yang memiliki nilai positif $0,0192 \%$ menjadi negatif $(0,379 \%)$. Perubahan negatif juga terjadi pada pasangan SMA $(10,50)$ dari $0,011 \%$ menjadi $(0,768 \%)$, SMA $(10,100)$ 
dari $(0,035 \%)$ menurun hingga $(0,163 \%)$. Sedangkan pada strategi EMA, hanya pasangan EMA $(10,50)$ yang mendapatkan performa negatif yakni dari $0,013 \%$ menjadi negatif $(8,006 \%)$.

Tingkat return yang sangat masif ini dsebabkan oleh penggandaan lot sebanyak 1,5 kali saat terjadi kerugian. Dan pada pasangan EMA $(10,100)$ kerugian beruntun terjadi setelah modal awal menanjak cukup tajam, sehingga modal trading dari strategi ini tetap bertahan dan malah memberikan hasil yang sangat besar dibandingkan strategi double MA cross lainnya.

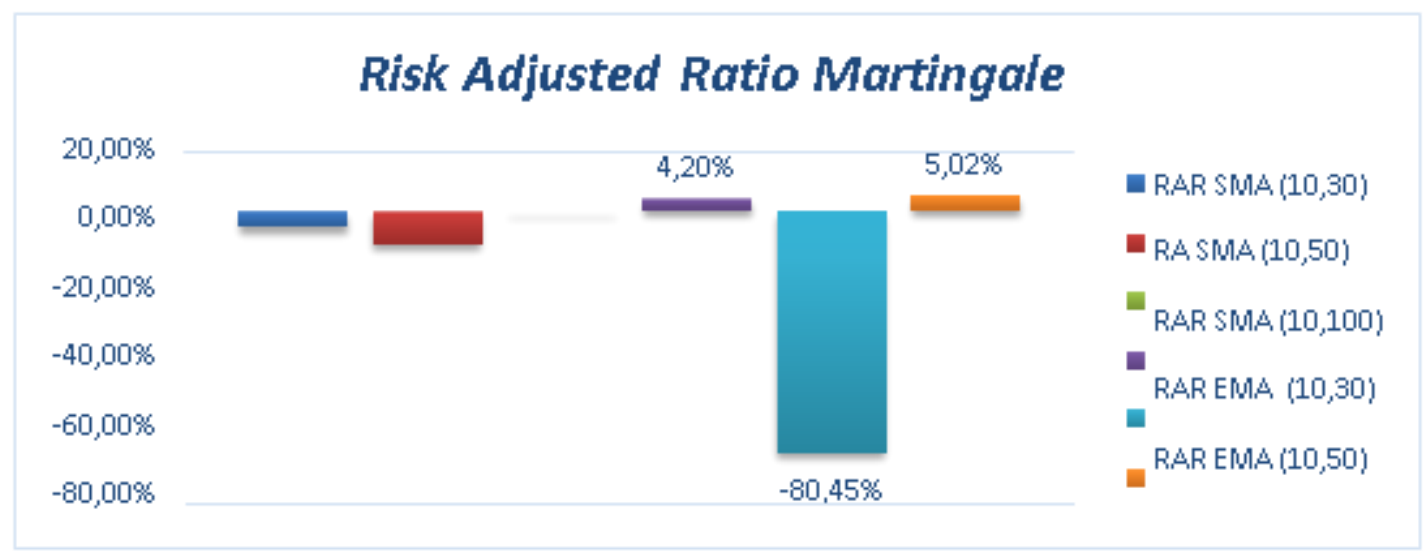

Gambar Grafik RAR Martingale Tahun 2010-2019

Hal ini sejalan dengan penelitian Wojtowicz (2016), yang melakukan penelitian berdasarkan perbandingan return antara beberapa metode money management dan salah satunya adalah martingale dimana metode ini memberikan return nyata sebesar $1.731,8 \%$ pada WARSAW stock exchange. Dan hipotesis ketiga (H3) yang menyatakan bahwa strategi metode money management martingale memberikan return yang lebih optimal dibandingkan fixed lot (tanpa money management) diterima.

\section{Perbandingan Metode Money Management Paling Optimal}

Dari hasil ekperimen simulasi backtest dalam ekperimen penelitian ini, didapati bahwa strategi aktif paling optimal pada masing-masing metode money management adalah pasangan EMA $(10,30)$ pada penggunaan metode money management fixed lot, pasangan EMA $(10,30)$ pada metode money management Fixed \% Lot, dan pasangan EMA $(10,100)$ pada metode money management martingale. Susunan performa dari masing-masing strategi tersebut diurutkan dari yang tertinggi hingga yang terendah berdasarkan imbal hasil yang dibukukan berdasarkan masing- masing metode money management dapat dilihat pada Tabel 4.3 berikut: 


\section{Urutan Hasil Strategi Aktif dalam Money Management Periode Januari 2010-Desember 2019}

\begin{tabular}{|c|c|c|c|c|c|c|c|c|c|}
\hline \multirow[b]{2}{*}{ Performa } & \multicolumn{2}{|c|}{ Fixed Lot } & \multirow[b]{2}{*}{$\begin{array}{c}\text { Total Return } \\
\%\end{array}$} & \multicolumn{2}{|c|}{ Fixed \% Lot } & \multirow[b]{2}{*}{ Total return } & \multicolumn{2}{|c|}{ Martingale } & \multirow[b]{2}{*}{ Total return } \\
\hline & Strategi & $\begin{array}{l}\text { Average } \\
\text { Return \% }\end{array}$ & & Strategi & $\begin{array}{l}\text { Average } \\
\text { Return \% }\end{array}$ & & Strategi & $\begin{array}{c}\text { Average } \\
\text { Return \% }\end{array}$ & \\
\hline Highest & $\begin{array}{c}\text { EMA } \\
(10,30)\end{array}$ & $0,036 \%$ & $69,353 \%$ & $\begin{array}{c}\text { EMA } \\
(10,30)\end{array}$ & $0,033 \%$ & $62,770 \%$ & $\begin{array}{c}\text { EMA } \\
(10,100)\end{array}$ & $6,314 \%$ & $6610,558 \%$ \\
\hline $2 \mathrm{nd}$ & $\begin{array}{c}\text { SMA } \\
(10,30)\end{array}$ & $0,019 \%$ & $42,304 \%$ & $\begin{array}{c}\text { SMA } \\
(10,30)\end{array}$ & $0,010 \%$ & $22,998 \%$ & $\begin{array}{c}\text { EMA } \\
(10,30)\end{array}$ & $1,784 \%$ & $3425,079 \%$ \\
\hline $3 \mathrm{rd}$ & $\begin{array}{c}\text { EMA } \\
(10,50)\end{array}$ & $0,013 \%$ & $19,130 \%$ & $\begin{array}{c}\text { EMA } \\
(10,50)\end{array}$ & $-0,003 \%$ & $-3,933 \%$ & $\begin{array}{c}\text { SMA } \\
(10,100)\end{array}$ & $-0,163 \%$ & $-63,344 \%$ \\
\hline $4 \mathrm{rd}$ & $\begin{array}{c}\text { SMA } \\
(10,50)\end{array}$ & $0,011 \%$ & $16,343 \%$ & $\begin{array}{c}\text { SMA } \\
(10,50)\end{array}$ & $-0,004 \%$ & $-6,100 \%$ & $\begin{array}{c}\text { SMA } \\
(10,30)\end{array}$ & $-0,379 \%$ & $-57,552 \%$ \\
\hline $5 \mathrm{rd}$ & $\begin{array}{c}\text { SMA } \\
(10,100\end{array}$ & $-0,035 \%$ & $-33,612 \%$ & $\begin{array}{c}\text { SMA } \\
(10,100\end{array}$ & $-0,039 \%$ & $-38,221 \%$ & $\begin{array}{l}\text { SMA } \\
(10,50\end{array}$ & $-0,768 \%$ & $-66,082 \%$ \\
\hline Lowest & $\begin{array}{c}\text { EMA } \\
(10,100)\end{array}$ & $-0,040 \%$ & $-42,212 \%$ & $\begin{array}{c}\text { EMA } \\
(10,100)\end{array}$ & $-0,045 \%$ & $-46,951 \%$ & $\begin{array}{c}\text { EMA } \\
(10,50)\end{array}$ & $-8,006 \%$ & $-96,067 \%$ \\
\hline
\end{tabular}

Sumber : data olahan.

Strategi yang memberikan hasil pada metode money management fixed lot adalah SMA $(10,100)$ dan EMA $(10,100)$. Sedangkan saat dilakukan perubahan metode money management Fixed \% Lot, strategi yang memberikan hasil negatif meningkat menjadi 4 pasangan double MA cross. Strategi tersebut adalah pasangan EMA $(10,50)$, SMA $(10,50)$, SMA $(10,100)$ dan EMA $(10,100)$. Hal yang sama terjadi pada metode money management martingale, kerugian yang dihasil menjadi lebih besar yakni SMA $(10,100)$, SMA $(10,30)$, SMA $(10,50)$ dan bahkan EMA $(10,50)$ mengalami kerugian hingga 96,07\%.

Meskipun perubahan dari hasil negatif ke positif setelah diterapkan metode money management maupun perubahan hasil positif ke negatif setelah dilakukan penerapan metode money management, mau itu metode Fixed \% Lot ataupun martingale terdapat satu pasangan double MA cross yang tetap memberikan hasil positif pada pasar futures emas selama periode ini. EMA $(10,30)$ merupakan satusatunya pasangan double MA cross yang membukukan hasil positif pada 3 jenis metode money management yang diteliti. Pada metode fixed lot, strategi ini membukukan hasil average return sebesar $0,036 \%$, kemudian meskipun terjadi penurunan pada metode Fixed \% Lot. Strategi ini tetap membukukan hasil yang positif dengan nilai average return sebesar 0,033\%. Bahkan strategi ini membukukan hasil melonjak drastis saat penerapan metode money management martingale. Average return yang dihasil EMA $(10,30)$ ini adalah sebesar 1,784\% dengan total return sebesar 3425,079\%.

Adapun hasil dari represntasi nilai rata-rata dari kelompok metode money management direpresentasikan dalam Tabel 4.4 : 


\section{Performa Rata-rata Metode Money Management pada Strategi Aktif Periode Januari 2010-Desember 2019}

\begin{tabular}{|l|l|l|l|}
\hline Keterangan & Fixed Lot & Fixed \% Lot & Martingale \\
\hline Average Return & $0,0078 \%$ & $-0,0010 \%$ & $2,7053 \%$ \\
\hline Standard Deviaton & $1,64721 \%$ & $2,03091 \%$ & $75,66209 \%$ \\
\hline Total Strategy Return & $71,306 \%$ & $-9,437 \%$ & $9752,591 \%$ \\
\hline Total Orders & 9165 & 9165 & 3605 \\
\hline Risk Adjusted Ratio (RAR) & $0,47233 \%$ & $-0,05070 \%$ & $3,57550 \%$ \\
\hline
\end{tabular}

Sumber : hasil olahan.

Dari diatas dapat dilihat bahwa metode money management martingale membukukan return rata-rata tertinggi diantara ketiga metode money management tersebut. Tingkat return rata-rata metode martingale adalah sebesar 2,7053\% dari total 3605 transaksi dari keenam strategi double MA cross. Imbal hasil akhir yang diperoleh metode martingale juga merupakan yang tertinggi yakni sebesar 9.752,591\% dengan nilai RAR sebesar 3,56550\%. Sedangkan nilai ratarata return kedua terbesar adalah metode fixed lot dengan nilai sebesar 0,0078\% dari 9165 transaksi dengan nilai RAR sebesar 0,47233\%. Imbal hasil akhir yang dibukukan metode fixed lot ini adalah ini adalah 71,306\%. Dan metode money management Fixed \% Lot memberikan hasil terendah dengan nilai rata-rata return yang negatif sebesar $(0,0010 \%)$ dari 9165 transaksi dengan nilai RAR sebesar $(0,05070 \%)$, dengan imbal hasil akhir yang dibukukan sebesar $(9,437 \%)$.

Hasil ini mendukung hipotesis keempat yaitu strategy Money management paling optimal memberikan return yang lebih baik dibandingkan return strategi buy and hold, maka dari itu H4 diterima. Hasil eksperimen ini juga selaras dengan penelitian Wojtowicz (2016), yang melakukan penelitian berdasarkan perbandingan return antara beberapa metode money management dan salah satunya adalah martingale dimana metode ini memberikan return nyata sebesar $1.731,8 \%$ pada WARSAW stock exchange.

\section{SIMPULAN}

1. Berdasarkan dari hasil simulasi backtest yang dilakukan imbal hasil yang diberikan masing-masing dari 6 (enam) strategi double MA cross yang diuji sangatlah beragam. Hasil positif dibukukan oleh pasangan SMA $(10,30)$, SMA $(10,50)$, EMA $(10,30)$, dan EMA $(10,50)$. Sedangkan pasangan SMA $(10,100)$ dan EMA $(10,100)$ membukukan hasil yang yang negatif. 
2. Strategi double MA cross dengan mode EMA pasangan 10 dan 30 memberikan imbal hasil yang paling optimal dengan tingkat pengembalian akhir sebesar 69,35\% dengan rata-rata return sebesar 0,036\% dan RAR sebesar 2,401\% selama periode Januari 2010 sampai dengan Desember 2019. Dan hasil ini menunjukkan performa yang lebih baik dibandingkan strategi pasif yakni strategi buy and hold dimana tingkat pengembaliannya adalah sebesar $20,20 \%$ dan tingkat rata-rata return sebesar 0,0085\% dan RAR sebesar 0,63\% dengan periode yang sama.

3. Berdasarkan hasil simulasi setelah penggunaan metode money management Fixed \% Lot, average return yang dihasilkan mengalami penurunan dan resiko yang terjadi saat penggunaan metode money management Fixed \% Lot mengalami peningkatan jika dibandingkan saat menggunakan metode fixed lot. Hasil ini dikarenakan recovering loss semakin mengecil saat penggunaan money management ini, terlebih lagi probabilitas win loss ratio pada setiap strategi adalah dibawah 50\%.

4. Setelah diimplementasikan metode money management martingale, strategi double MA cross yang paling optimal pada pasar futures emas adalah pasangan EMA 10 dan 100 dengan tingkat pengembalian sebesar 6.610,56\% dengan rata-rata return sebesar 6,314\% dan RAR sebesar 5,02 \% yang dimana hasil ini juga memberikan return yang lebih tinggi dibandingkan strategi pasif. Tingkat pengembalian ini menunjukkan bahwa jika seorang trader menginvestasikan $\$ 10.000$ dengan menggunakan strategi EMA $(10,100)$ dengan metode martingale 1,5x pada awal Januari 2010, maka pada akhir Desember 2020 balance akan menjadi $\$ 661.055$,8. Pasangan double MA cross EMA $(10,30)$ merupakan satu-satunya strategi yang membukukan imbal hasil yang positif pada penerapan ketiga jenis metode money management. Total return EMA $(10,30)$ pada money management fixed lot adalah $69,35 \%$, pada metode money management Fixed \% Lot total return yang dihasilkan adalah sebesar $62,77 \%$ sedangkan total return EMA $(10,30)$ saat menggunakan metode money management martingale memberikan performa optimal dengan total return sebesar $3425,08 \%$.

5. Dari hasil perbandingan rata-rata money management fixed lot, Fixed \% Lot, dan martingale. Metode money management yang memberikan performa paling tinggi adalah martingale. Sedangkan metode money management Fixed \% Lot memberikan hasil yang negatif dan membuat kinerja strategi aktif menjadi lebih rendah. Sedangkan fixed lot memberikan imbal hasil positif tergantung dari kinerja strategi aktif tersebut. Dapat dsimpulkan bahwa efektifitas metode martingale lebih optimal dibandingkan dengan metode fixed lot. Sedangkan metode Fixed \% Lot memberikan performa yang lebih rendah dibandingkan dengan metode fixed lot. 
6. Hasil ekperimen expert advisor dalam penelitian menujukkan variasi imbal hasil yang diberikan. Terdapat beberapa pasangan MA dengan kombinasi money management yang memberikan hasil yang lebih optimal ketimbang strategi buy and hold. Rekomendasi dalam implikasinya berdasarkan risk tolerance para trader maupun investor dalam aplikasi penggunaan expert advisor yang diteliti dalam penelitian ini disusun dalam matriks yang tersaji pada Tabel 5.1 berikut :

\section{Rekomendasi Implikasi Penggunaan Expert Advisor Strategi Double MA Cross dan Money Management Berdasarkan Risk Tolerance Investor}

\begin{tabular}{|c|c|c|c|c|}
\hline $\begin{array}{c}\text { Risk } \\
\text { Tolerance }\end{array}$ & $\begin{array}{c}\text { Double MA } \\
\text { Cross }\end{array}$ & $\begin{array}{c}\text { Money } \\
\text { Management }\end{array}$ & $\begin{array}{c}\text { Standar } \\
\text { Deviation }\end{array}$ & Net Return \\
\hline Conservative & EMA (10,30) & Fixed Lot & $1,505 \%$ & $69,353 \%$ \\
\hline Moderate & EMA (10,30) & Fixed Lot & $1,505 \%$ & $69,353 \%$ \\
\hline Aggressive & EMA (10,100) & Martingale $(1,5 x)$ & $125,769 \%$ & $6.610,56 \%$ \\
\hline
\end{tabular}

Untuk trader / investor yang bertipe conservative dan moderate disarankan memilih strategi double MA cross pasangan EMA $(10,30)$ dengan metode money management fixed lot karena memberikan net return yang lebih tinggi jika dibandingkan dengan strategi buy and hold yakni sebesar 69,353\%. Serta memberikan resiko yang lebih rendah dengan representasi standar deviasi sebesar 1,505\%. Untuk investor bertipe agrresive, akan lebih cocok menggunakan strategi EMA $(10,100)$ dengan metode martingale yang dapat meningkatkan balance trading mereka dari $\$ 10.000$ menjadi $\$ 661.056$ dalam kurun waktu 10 tahun dengan resiko yang yang besar. 


\section{REFERENSI}

Anghel, Dan. (2013). How Reliable Is the Moving Average Crossover Rule for an Investor on the Romanian Stock Market?. Review of Finance and Banking. 5. 89-115

Bappebti. (2017). Sekilas Tentang Perdagangan Berjangka Komoditi [Online]. http://bappebti.go.id/brosur_leaflet/detail/126 [Accessed 18 Agusutus 2019].

Bappebti. (2018). SK Kep. Kepala Bappebti [Online]. http://website.bappebti.go.id/id/regulation/decision/detail/2468.html [Accessed 18 Agustus 2019].

Boonkrong, Pichit \& Yangnoy, Thapanapong. (2017). A Comparative Study of Dual Moving Average Crossover Trading Strategies in SET50 Index: Simple Vs. Exponential Moving Averages (ภาษาไทย).

Breiman, L. Optimal Gambling Systems for Favorable Games. Proceedings of the Fourth Berkeley Symposium on Mathematical Statistics and Probability, Volume 1: Contributions to the Theory of Statistics, 65--78, University of California Press, Berkeley, 1961. https://projecteuclid.org/euclid.bsmsp/1200512159

Caginalp, Gunduz and Balevonich, Donald, A Theoretical Foundation for Technical Analysis. Journal of Technical Analysis, Vol. 59, No. 5-22, 2003. Available at SSRN: https://ssrn.com/abstract $=658165$

Chan, Lanz and Wong, Wing-Keung, Automated Trading with Genetic-Algorithm Neural-Network Risk Cybernetics: An Application on FX Markets (February 20, 2012). Finamatrix Journal, February 2012 . Available at SSRN: https://ssrn.com/abstract $=1687763$

Chan, Lanz and Wong, Wing-Keung, Expert Advisor Development on MT4/MT5 for Automated Algorithmic Trading on EURUSD M1 Data (September 1, 2013). Finamatrix Journal, September 2013. Available at SSRN: https://ssrn.com/abstract=2319073

Dimitrios Vezeris \& Themistoklis Kyrgos \& Christos Schinas, 2018. "Take Profit and Stop Loss Trading Strategies Comparison in Combination with an MACD Trading System," Journal of Risk and Financial Management, MDPI, Open Access Journal, vol. 11(3), pages 1-23, September. 
ANALISIS IMBAL HASIL DENGAN AUTOMATIC TRADING DALAM PERSPEKTIF MONEY MANAGEMENT: STUDI EKSPERIMENTAL DENGAN EXPERT ADVISOR PADA PASAR FUTURES

Paulus Candra a

Doob, J. L. (2013). What is Martingale?. Retrieved November 20, 2014, from http://www.jstor.org/discover/10.2307/2317751?sid=211060155932 03\&uid $=4$ \&uid $=2134 \&$ uid $=2$ \&uid $=3738672 \&$ uid $=70$

Glabadanidis, Paskalis, Market Timing with Moving Averages (November 9, 2012). 25th Australasian Finance and Banking Conference 2012. Available at SSRN: $\quad$ https://ssrn.com/abstract=2127483 http://dx.doi.org/10.2139/ssrn.2127483

Gurrib, Ikhlaas, The Moving Average Crossover Strategy: Does It Work for the S\&P500 Market Index? (November 30, 2014). Gurrib, I. (2016), Optimization of the Double Crossover Strategy for the S\&P500 Market Index, Global Review of Accounting and Finance, Vol. 7. No. 1. , March 2016, Pages: 92-107. Available at SSRN: https://ssrn.com/abstract $=2578302$ or http://dx.doi.org/10.2139/ssrn.2578302 